Bài báo khoa học

\title{
Nghiên cứu mức độ ô nhiễm vi nhựa trong nước và trầm tích sông Sài Gòn-Đồng Nai
}

\author{
Huỳnh Phú ${ }^{*}$, Huỳnh Thị Ngọc Hân², Nguyễn Lý Ngọc Thảo ${ }^{1}$ Đặng Văn Đông ${ }^{3}$, Trịnh \\ Gia Hân ${ }^{4}$ \\ ${ }^{1}$ Trường Đại học công nghệ TP Hồ Chí Minh, (HUTECH); h.phu@hutech.edu.vn; \\ nln.thao@hutech.edu.vn; \\ ${ }^{2}$ Trường Đại học Tài nguyên và môi trường TP Hồ Chí Minh; \\ htnhan_ctn@hcmunre.edu.vn; \\ ${ }^{3}$ Công ty TNHH TM DV Đông vinh; sales@dovitech.com.vn; \\ ${ }^{4}$ Học viên cao học; giahann1296@gmail.com. \\ *Tác giả liên hệ: h.phu@hutech.edu.vn; Tel.: +84-9666 87548
}

Ban Biên tập nhận bài: 14/6/2021; Ngày phản biện xong: 19/8/2021; Ngày đăng bài: $25 / 11 / 2021$

Tóm tắt: Sông Sài Gòn-Đồng Nai, nơi cung cấp đến $94 \%$ nguồn nước thô để sản xuất nước ăn uống và sinh hoạt cho nhân dân TP Hồ Chí Minh. Bài báo trình bày phương pháp lấy mẫu tại 18 vị trí (13 vị trí trên sông Sài Gòn và 5 vị trí trên sông Đồng Nai), phân tích vi nhựa trong môi trường nước mặt, trầm tích. Nguồn nước không chỉ ô nhiễm hữu cơ và các thông số hóa lý mà còn ô nhiễm do phát thải vi nhựa. Kết quả cho thấy xuất hiện vi nhựa dạng mảnh, dạng sợi và hạt vi nhựa từ kích thước $0,1-5 \mathrm{~mm}$. Có $228.120 \mathrm{sợi} / \mathrm{m}^{3}$ nước đến nhiều nhất $715.124 \mathrm{sợi} / \mathrm{m}^{3}$ nước và 11 đến $222 \mathrm{mảnh} / \mathrm{m}^{3}$ nước, trong trầm tích $6,47 \pm 1,45$ đến $52,32 \pm 4,92 \mathrm{mg} / \mathrm{kg}$, trung bình $21,77 \pm 6,9 \mathrm{mg} / \mathrm{kg}$. Trong đó $\mathrm{PE} 51,2 \%$, PP 27,1\%, PVC 13,4\% và 8,3\% là các loại nhựa khác.

Từ khóa: Nước mặt; Sông Sài Gòn-Đồng Nai; Trầm tích; Vi nhựa.

\section{Giới thiệu}

Vi nhựa (microplastic) là những phân tử nhựa rất nhỏ mà mắt thường không nhìn thấy được với kích thước từ $0,3-5 \mathrm{~mm}[1]$. Vi nhựa được phân loại thành nhóm vi nhựa sơ cấp do con người tạo ra, bao gồm hạt vi nhựa (microbead), sợi vi nhựa (microfiber) và hạt nhựa (plastic pellet/plastic nurdle). Nhóm nhựa thứ cấp được hình thành từ sự phân rã của các sản phẩm lớn hơn được làm từ nhựa. Các sản phẩm này được đưa vào môi trường do các tác nhân vật lý, sinh học và hoá học. Những sản phẩm điển hình phân rã ra thành vi nhựa là chai nước, lưới đánh cá và túi nhựa, quần áo, bảo hộ y tế, khẩu trang...cunng là nguồn phân rã ra thành vi nhựa. Hạt vi nhựa là những khối nhựa đặc với kích thước $1 \mathrm{~mm}$ trở xuống, sợi vi nhựa nằm trong nhóm vi nhựa sơ cấp, đường kính của chúng nhỏ hơn $10 \mu \mathrm{m}$. Chúng là những sợi nhựa có nguồn gốc từ vải tự nhiên và vải tổng hợp, với thành phần chủ yếu bao gồm polyester, nylon. Các loại vải microfiber không hề thân thiện với môi trường, bởi polyester và nylon được làm từ các chất hoá dầu. Chúng không thể tái chế hay phân huỷ sinh học, chỉ có vải microfiber được làm từ polypropylene mới có khả năng tái chế [2-4]. Được sinh ra chủ yếu từ các mặt hàng tiêu dùng, những mảnh nhựa có trong rác thải, túi nilon, bao bì nhựa, bụi trong quá trình mài mòn của sợi vi nhựa khi giặt quần áo, khẩu 
trang, đồ chơi bằng nhựa, vi nhựa cao su do lốp xe hao mòn....[2-4]. Hiện nay, trên thế giới đã dành rất nhiều quan tâm trong việc nghiên cứu vấn đề rác thải vi nhựa trong môi trường nước mặt, trong sông ngòi và trên các đại dương. Nhưng có rất ít tài liệu công bố nghiên cứu về ô nhiễm vi nhựa cho vùng nước nước ngọt nội địa, hầu như các thông tin dữ liệu chứng minh sự có mặt của vi nhựa trong sông vẫn còn rất hạn chế. Các con sông và biển, đại dương trên thế giới đã được chứng minh là ô nhiễm vi nhựa nặng, đặc biệt là tại các cửa sông [5]. Mặc dù rác thải nhựa không phải là một vấn đề mới, nhưng chỉ gần đây vi nhựa mới trở thành tâm điểm của cộng đồng khoa học với các báo cáo về chủ đề này ngày càng tăng nhanh, đặc biệt là trong các hệ thống biển và cửa sông [6-8]. Vi nhựa có xu hướng tích tụ trong trầm tích ở sông hồ thông qua trầm tích hóa bởi vì trầm tích phản ánh sự tương tác lâu dài giữa nước và đất [9-12]. Tích tụ của vi nhựa trong trầm tích bờ biển của 18 quốc gia, Việt Nam đứng thứ 4 theo The Wall Street Journal 2010 từ sáu lục địa, cho thấy sự ô nhiễm bởi vi nhựa trên quy mô toàn cầu [13]. Ngoài ra nhiều thông tin nghiên cứu đã khẳng định trầm tích đáy sông và đại dương chứa đựng rất nhiều vi nhựa [14-19]. Vi nhựa ngày càng ô nhiễm với mật độ cao, tích tụ theo thời gian và đặc tính bền với môi trường [20-22]. Các minh chứng kết quả nghiên cứu mật độ vi nhựa cao trong môi trường nước sông và trầm tích đã được xác nhận rõ ràng. Mức độ ô nhiễm vi nhựa tương quan với các khu vực đô thị, vi nhựa ở nhiều dạng khác nhau như sợi, mảnh, viên và hạt trong môi trường nước và đến từ hai nguồn chính, đó là nguồn gốc từ thủy sinh và nguồn trên đất liền [23-24]. Gần đây, sự đa dạng về thành phần và kết cấu bề mặt của vi nhựa trong trầm tích của các vùng nước đô thị trên thế giới đã được nghiên cứu ở Trung Quốc và nước Anh [2526]. Các tác giả đã tìm ra sự phân bố của vi nhựa trong trầm tích của các hồ trong đô thị có nồng độ cao và đã gây bất lợi cho các sinh vật đáy. Đánh giá khả năng phân bố polystyrene trên mô hình thực nghiệm cho thấy chỉ sau 15 phút theo đường uống một liều các hạt polystyrene thì có $6 \%$ số hạt đã vào ngay tới vòng tuần hoàn [2]. Loại nhựa polystyrene đã được Cơ quan nghiên cứu Ung thư Thế giới (International Agency for Research on Cancer - ICRA) phân loại thuộc nhóm $2 \mathrm{~B}$ - nhóm chất có khả năng gây ung thư trên người. Phơi nhiễm polystyrene có thể gây đột biến gen, phá huỷ DNA, nguy cơ gây nhiễm bệnh ung thư [3-4].

Phân tích mới ở Anh đã phát hiện ô nhiễm vi nhựa ở tất cả 10 hồ, sông và các hồ chứa được lấy mẫu. Có hơn 1.000 mảnh nhựa nhỏ trên mỗi lít nước ở sông Tame, Manchester, Anh. Ngay cả ở những nơi tương đối xa như Thác nước Dochart và Loch Lomond ở Scotland cũng chứa 2 hoặc 3 mảnh nhựa trên mỗi lít nước. Sông Thames ở London có khoảng 80 vi nhựa trên mỗi lít nước, tương tự như sông Cegin ở Bắc Wales. Sông Blackwater ở Essex có 15 hạt vi nhựa. Ullswater có 30 hạt và hồ chứa Llyn Cefni ở Anglesey có 40 hạt [11]. Tại Việt Nam, từ 2000 đến 13.000 tấn mảnh vụn nhựa trôi nổi được thu thập hàng năm trên các kênh chính của đô thị [2-4].

Nghiên cứu về đặc trưng ô nhiễm vi nhựa trong nước mặt tại 3 vùng biển, Tiền Giang, Cần Thơ và Bà Rịa-Vũng Tàu. Nồng độ ô nhiễm vi nhựa cao nhất ở vùng biển Tiền Giang và thấp nhất ở vùng biển Cần Thơ, kích thước vi nhựa dao động khoảng $0,25-0,5 \mathrm{~mm}$ và $1-$ $2,8 \mathrm{~mm}$, với màu sắc khá đa dạng [6]. Tại khu vực Cần Giờ và cửa Ba Lạt đã cho thấy dấu hiệu nhiễm bẩn của rác thải nhựa trong môi trường. Tuy nhiên, các nghiên cứu này chưa đưa ra nội dung cụ thể về quy trình tách và phân loại vi nhựa trong môi trường trầm tích phù hợp với điều kiện Việt nam. Gần đây cũng đã có những kết quả nghiên cứu phương pháp xác định hạt vi nhựa trong môi trường trầm tích bãi triều ven biển, áp dụng thử nghiệm tại xã Đa Lộc, huyện Hậu Lộc, tỉnh Thanh Hóa. Trầm tích bãi triều có hàm lượng hạt vi nhựa từ $0,02-0,0798 \mathrm{~g} / \mathrm{kg}$ với giá trị trung bình $0,0229-0,0089 \mathrm{~g} / \mathrm{kg}$, tương ứng với 2532-6875 mảnh vi nhựa/kg trầm tích [4]. Các nghiên cứu mô tả chung chung, chưa có phân tích định lượng về số lượng, về kích cỡ hạt, những tác hại đến con người và sinh vật [2]... Vì vậy, còn thiếu cơ sở khoa học để đề xuất các giải pháp bảo vệ nguồn nước khi xả thải nước thải vào môi trường nước mặt; đây cũng còn là vấn đề cấp bách cần được quan 
tâm. Nồng độ vi nhựa được quan sát thấy ở các vịnh thấp hơn nồng độ vi nhựa được ghi nhận tại các sông. Cụ thể, ở các sông, vi nhựa thể hiện sự biến đổi nồng độ đa dạng từ 2,3 hạt $/ \mathrm{m}^{3}$ ở sông Hồng đến 2.522 hạt $/ \mathrm{m}^{3}$ ở sông Tô Lịch với nồng độ thấp hơn ở sông chính và nồng độ cao hơn ở các sông nhỏ và đô thị, đặc biệt ở các vùng tiếp nhận nước thải chưa qua xử lý. Trong các vịnh, nồng độ vi nhựa thay đổi từ 0,4 hạt $/ \mathrm{m}^{3}$ ở vịnh Cửa Lục đến 28,4 hạt $/ \mathrm{m}^{3}$ ở cửa sông Dinh [12].

Các kết quả nghiên cứu gần đây cho thấy chất lượng nước sông Sài Gòn-Đồng Nai đang có những chuyển biến xấu đi rất nhiều, đặc biệt là sự có mặt của vi nhựa [2]. Sông Sài Gòn được đánh giá là con sông thải ra nhiều nhựa thứ 5 ở Việt Nam và thứ 45 trên thế giới [2]. Ước tính hàng năm có khoảng $115-164 \times 10^{12}$ hạt vi nhựa dạng sợi nhân tạo được thải vào vùng nước sông Sài Gòn [4]. Nghiên cứu phương pháp khảo sát sự phát thải vi nhựa ra biển, áp dụng ở sông Sài Gòn cho thấy trong tổng $660 \mathrm{~kg}$ mẫu phát hiện được 7,6\% là nhựa (dựa theo khối lượng), 90,7\% là hợp chất hữu cơ và $1,7 \%$ vật liệu còn lại. Hay nghiên cứu được thực hiện tại kênh Nhiêu Lộc-Thị Nghè cho thấy sự tồn tại chủ yếu của sợi và mảnh vỡ nhựa với nồng độ tương ứng là từ 72.000 đến $519.000 \mathrm{sợi} / \mathrm{m}^{3}$ nước và 10 đến 223 mảnh/ $\mathrm{m}^{3}$ nước [26]. Ước tính tổng lượng mảnh vụn nhựa ở thượng lưu sông Sài Gòn là $1,1 \times 10^{3}$ tấn/năm vào năm $2018\left(1,4-1,6 \times 10^{3}\right.$ tấn/năm nếu ngoại suy trên tổng lượng nước) [19]. Theo kết quả nghiên cứu trên sông Sài Gòn mật độ vi nhựa dạng sợi tại mồi điểm từ 172.000 sợi vi nhựa $/ \mathrm{m}^{3}$ nước đến 519.000 sợi vi nhựa $/ \mathrm{m}^{3}$ nước; dạng mảnh từ $10 \mathrm{mảnh} / \mathrm{m}^{3}$ nước đến 223 mảnh $/ \mathrm{m}^{3}$ nước [13]. Ở vùng biển Tiền Giang, Cần Giờ và Bà Rịa-Vũng Tàu, mật độ vi nhựa dao động từ $0,04-0,82$ sợi vi nhựa $/ \mathrm{m}^{3}$ nước biển, thấp nhất ở vùng Cần Giờ và cao nhất ở vùng Tiền Giang [15]. Những tác động của hạt vi nhựa lên sức khỏe con người và động vật phụ thuộc vào nồng độ, thời gian phơi nhiễm. Do kích thước rất nhỏ và tính kỵ nước của các hạt vi nhựa, giúp chúng dễ dàng đi qua hàng rào nhau thai cũng như máu não, có thể vào đường tiêu hóa và phổi, những vị trí tiềm ẩn nguy cơ bị tổn thương. Khi vào cơ thể, chúng có thể gây stress oxy hóa các tế bào, dẫn đến kích hoạt nhiễm trùng, suy giảm hệ miễn dịch, rối loạn quá trình nội tiết. Nguy cơ ảnh hưởng đến sức khoẻ con người và sinh vật khi tiếp nạp hạt vi nhựa vào cơ thể. Sự tích luỹ sinh học và độc tính của hạt vi nhựa trên động vật có vú, tuy nhiên, cũng như những chất độc hại khác, những tác động của hạt vi nhựa lên sức khoẻ con người và động vật phụ thuộc vào thời gian phơi nhiễm và nồng độ. Đặc tính kỵ nước và kích thước nhỏ, các hạt vi nhựa có thể vào đường tiêu hoá và phổi, những vị trí tiềm ẩn nguy cơ bị tổn thương. Đồng thời các hạt vi nhựa có khả năng hấp phụ các vi sinh vật hay chất ô nhiễm độc hại. Khi vào cơ thể, chúng có thể kích hoạt nhiễm trùng, suy giảm hệ miễn dịch, rối loạn quá trình nội tiết. Phân tử nhựa dạng sợi còn được tìm thấy trong phổi người, các công trình nghiên cứu chỉ ra rằng hạt vi nhựa tồn tại trong không khí là nguyên nhân chính gây ra và làm cho tế bào phổi sản xuất các chất kháng viêm theo tự nhiên.

Nhiều nhà nghiên cứu cảnh báo, các loại khẩu trang chứa chất dẻo vi mô và nano cùng các chất độc hại khác gây ra nguy cơ tiềm ẩn cho môi trường. Chúng ta sử dụng 129 tỷ chiếc khẩu trang trên toàn cầu mối tháng, tức là 3 triệu chiếc mỗi phút. Hầu hết chúng là khẩu trang dùng một lần được làm từ các sợi vi nhựa [11]. Với việc ngày càng có nhiều báo cáo về vứt bỏ khẩu trang không đúng chỗ, cần phải nhận ra mối đe dọa môi trường tiềm ẩn này và ngăn chặn nó trở thành vấn nạn tiếp theo về ô nhiễm nhựa. TP.HCM mỗi ngày phải xử lý khoảng 9.000 tấn rác thải sinh hoạt, cơ sở hạ tầng, quản lý chất thải rắn, hệ thống xử lý rác thải chủ yếu là chôn lấp. Thời gian phân hủy các chất hữu cơ trong nước từ 7-15 ngày, nhưng những sản phẩm là vật dụng như chai nước nhựa, túi ni-lông, khẩu trang, bàn chải đánh răng... thời gian phân hủy từ 50-500 năm. Quá trình phân hủy không làm nhựa biến mất mà chuyển thành những hạt vi nhựa. Hạt vi nhựa đi vào nước thải, ao, sông rạch, mạch nước ngầm... khi tôm cá, động vật ăn hoặc uống nguồn nước này đều có hạt vi nhựa trong cơ thể. Do đó, con người có thể nuốt những hạt vi nhựa thông qua nguồn thức ăn như muối, rau củ, tôm cá, nước uống đã nhiễm hạt vi nhựa. 
Nghiên cứu xác định mức độ phát thải vi nhựa trong nước và trầm tích sông Sài GònĐồng Nai. Bổ sung dữ liệu về mức độ ô nhiễm vi nhựa trong nước, trầm tích và tính toán được tỉ lệ thành phần vi nhựa trong hệ thống nước mặt làm cơ sở dữ liệu cho công tác bảo vệ môi trường nước sông Sài Gòn-Đồng Nai.

\section{Phương pháp nghiên cứu}

\subsection{Khảo sát thực địa và lấy mẫu}

Công tác khảo sát lấy mẫu nước và trầm tích, thông tin chi tiết thu thập được từ sự khác biệt về không gian, thời gian của ô nhiễm nhựa sẽ giúp xác định các nguồn trực tiếp hoặc nguồn phát tán của các hạt nhựa. Các nguồn trực tiếp như rác thải các khu đông dân cư, vận chuyển rác nhựa từ sông này sang sông khác trong khu vực lấy mẫu. Nghiên cứu được thực hiện trên sông Sài Gòn-Đồng Nai, nhánh sông Sài Gòn từ hồ Dầu Tiếng đến ngã ba sông Vạm Thuật 3 (khu vực giáp Huyện Hóc Môn và Thị trấn Lái Thiêu) đến cửa sông Sài gòn (ngã ba sông Sài Gòn-Đồng Nai) (Hình 1). Mười ba điểm lấy mẫu (mẫu nước mặt và trầm tích) được bố trí trên các ngã ba giao nhau giữa sông Sài Gòn-Đồng Nai và các kênh, rạch chính chảy ra từ các khu dân cư, khu công nghiệp, và khu nông nghiệp/đất tự nhiên vào sông. Trong 13 vị trí được lấy mẫu đơn nước mặt và trầm tích. Trong đó, các điểm từ số 2-SGL3, 3-SGL5, 6-SGL8, 9-SGL13, 10-SGL14 (bảng 1), được lấy mẫu kép (mẫu $a$ và $b$ ). Mẫu a là lấy trên sông Sài gòn, xung quanh ngã ba sông, và mẫu $b$ được lấy trên cửa kênh/rạch (cách mép sông Sài gòn khoảng 20-50 m về phía trong kênh/rạch). Nhánh sông Đồng Nai cũng được thực hiện theo bố trí tương tự trên 5 vị trí lấy mẫu, tại các vị trí 15-DNL2, 16-DNL5, 17-DNL6, 18-DNL8 (Bảng 1). Việc lấy mẫu như vậy để đảm bảo tính chính xác khi đánh giá ảnh hưởng của các dòng chảy vào sông Sài Gòn-Đồng Nai.

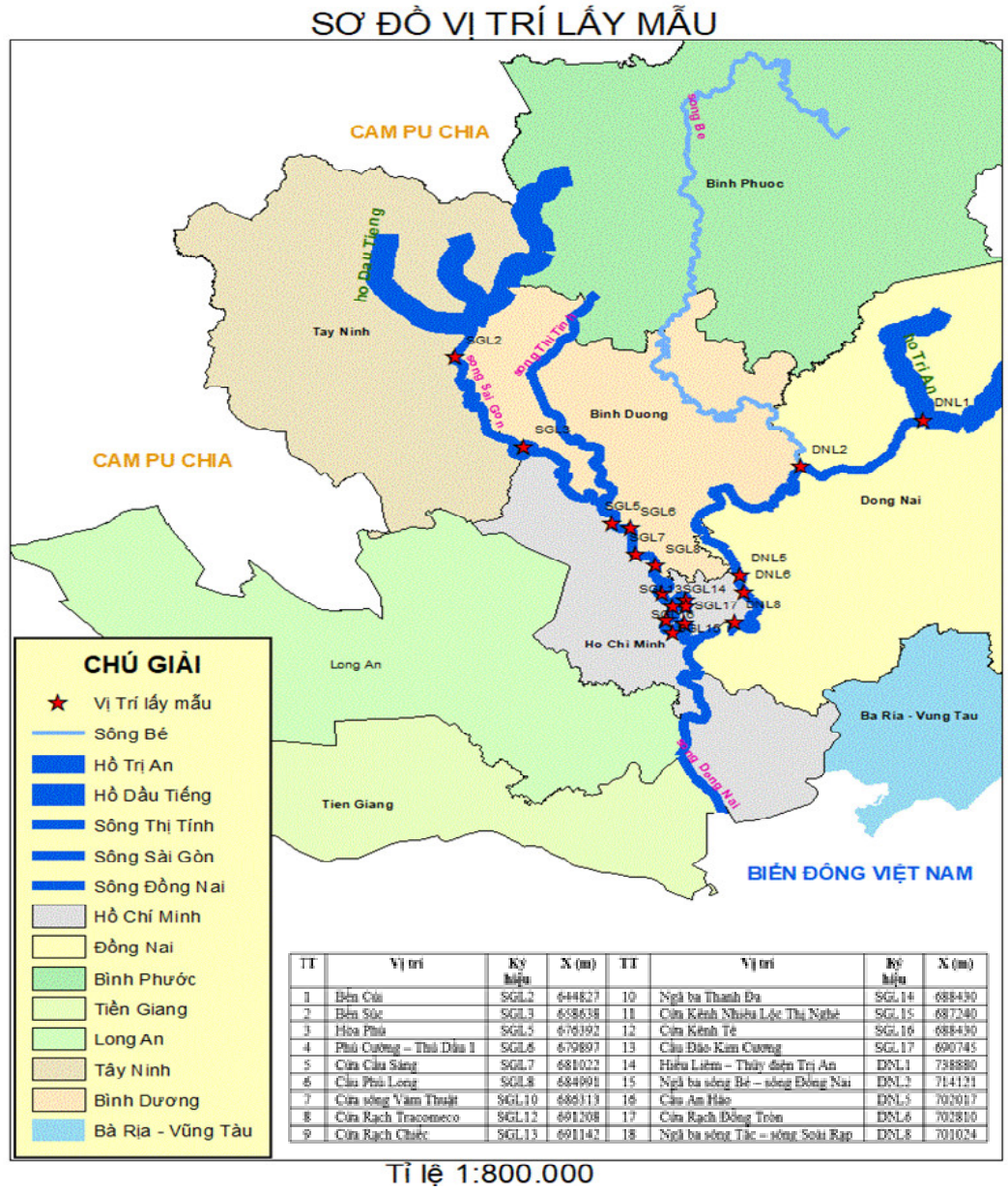

Hình 1. Sơ đồ vị trí lấy mẫu. 
Bảng 1. Danh mục vị trí lấy mẫu sông Sài Gòn-Đồng Nai.

\begin{tabular}{|c|c|c|c|c|c|c|}
\hline No. & Vị trí & Ký hiệu & $\mathbf{X}(\mathbf{m})$ & $\mathbf{Y}(\mathbf{m})$ & Mô tả & $\begin{array}{c}\text { Lý do lựa chọn } \\
\text { vị trí lấy mẫu }\end{array}$ \\
\hline \multicolumn{7}{|c|}{ Sông Sài Gòn } \\
\hline 1 & Bến Củi & SGL2 & 644827 & 1254580 & $\begin{array}{l}\text { Cầu Dầu tiếng sông Sài } \\
\text { Gòn, thị trấn Dầu Tiếng, } \\
\text { Tây Ninh }\end{array}$ & $\begin{array}{l}\text { Thượng nguồn sông Sài } \\
\text { Gòn từ hồ Dầu Tiếng } \\
\text { chảy ra }\end{array}$ \\
\hline 2 & Bến Súc & SGL3 & 658638 & 1233625 & $\begin{array}{l}\text { Sông Sài Gòn, cách } \\
\text { cầu Bến súc } 200 \mathrm{~m}\end{array}$ & $\begin{array}{l}\text { Phần sông Sài Gòn khi } \\
\text { vào địa phận TP.HCM }\end{array}$ \\
\hline 3 & Hòa Phú & SGL5 & 676392 & 1215574 & $\begin{array}{l}\text { Tại trạm bơm Hòa Phú } \\
\text { trên sông Sài Gòn }\end{array}$ & Tại trạm bơm Hòa phú \\
\hline 4 & $\begin{array}{l}\text { Phú Cường } \\
\text {-Thủ Dầu } \\
\text { Một }\end{array}$ & SGL6 & 679897 & 1214384 & $\begin{array}{l}\text { Cầu Phú Cường trên } \\
\text { sông Sài Gòn }\end{array}$ & $\begin{array}{l}\text { Sông Sài Gòn chảy qua } \\
\text { TP Thủ Dầu Một Bình } \\
\text { Dương }\end{array}$ \\
\hline 5 & $\begin{array}{l}\text { Cửa Cầu } \\
\text { Sáng }\end{array}$ & SGL7 & 681022 & 1208298 & $\begin{array}{l}\text { Vị trí cửa ra của Cầu } \\
\text { sáng-sông Sài Gòn }\end{array}$ & $\begin{array}{l}\text { Sông Cầu Sáng trước } \\
\text { khi hợp lưu với sông } \\
\text { Sài Gòn }\end{array}$ \\
\hline 6 & $\begin{array}{l}\text { Cầu Phú } \\
\text { Long }\end{array}$ & SGL8 & 684991 & 1205652 & $\begin{array}{l}\text { Cầu Phú Long trên sông } \\
\text { Sài Gòn }\end{array}$ & $\begin{array}{l}\text { Vị trí sau khi chảy qua } \\
\text { Lái Thiêu, Dĩ An Bình } \\
\text { Dương }\end{array}$ \\
\hline 7 & $\begin{array}{l}\text { Cửa sông } \\
\text { Vàm Thuật }\end{array}$ & SGL10 & 686313 & 1199038 & $\begin{array}{l}\text { Cửa ra của sông Vàm } \\
\text { Thuật-sông Sài Gòn }\end{array}$ & $\begin{array}{l}\text { Từ sông Vàm Thuật } \\
\text { trước khi hợp lưu sông } \\
\text { Sài Gòn }\end{array}$ \\
\hline 8 & $\begin{array}{l}\text { Cửa rạch } \\
\text { Tracomeco }\end{array}$ & SGL12 & 691208 & 1197649 & $\begin{array}{l}\text { Ngay vị trí cửa ra của } \\
\text { Rạch Tracomeco-sông } \\
\text { Sài Gòn }\end{array}$ & $\begin{array}{l}\text { Từ Rạch Tracomeco } \\
\text { (Nhiệt điện Thủ Đức) } \\
\text { trước khi hợp lưu với } \\
\text { sông Sài Gòn }\end{array}$ \\
\hline 9 & $\begin{array}{l}\text { Cửa Rạch } \\
\text { Chiếc }\end{array}$ & SGL13 & 691142 & 1195995 & $\begin{array}{l}\text { Ngay vị trí cửa ra của } \\
\text { Rạch Chiếc-sông Sài } \\
\text { Gòn }\end{array}$ & $\begin{array}{l}\text { Từ Rạch Chiếc (dòng } \\
\text { chảy Cảng Phước Long) } \\
\text { khi hợp lưu với sông } \\
\text { Sài Gòn }\end{array}$ \\
\hline 10 & $\begin{array}{l}\text { Ngã ba } \\
\text { Thanh Đa }\end{array}$ & SGL14 & 688430 & 1196061 & Cầu Kinh, Bình Thạnh & $\begin{array}{l}\text { Vị trí hợp lưu Kênh } \\
\text { Thanh Đa và sông Sài } \\
\text { Gòn hạ nguồn }\end{array}$ \\
\hline 11 & $\begin{array}{l}\text { Cửa Kênh } \\
\text { Nhiêu Lộc } \\
\text { Thị Nghè }\end{array}$ & SGL15 & 687240 & 1192886 & Công viên Cảng Ba Son & $\begin{array}{l}\text { Từ Kênh Nhiêu Lộc Thị } \\
\text { Nghè trước khi hợp } \\
\text { lưu với sông Sài Gòn }\end{array}$ \\
\hline 12 & $\begin{array}{l}\text { Cửa Kênh } \\
\text { Tẻ }\end{array}$ & SGL16 & 688430 & 1189976 & Cảng Tân Thuận & $\begin{array}{l}\text { Từ Kênh Tẻ trước } \\
\text { hợp lưu với sông Sài } \\
\text { Gòn }\end{array}$ \\
\hline 13 & $\begin{array}{l}\text { Cầu Đảo } \\
\text { Kim cương }\end{array}$ & SGL17 & 690745 & 1192026 & $\begin{array}{l}\text { Cầu Đảo Kim Cương/ } \\
\text { Cầu Thời Đại }\end{array}$ & $\begin{array}{l}\text { Từ Giồng Ông Tố trước } \\
\text { khi hợp lưu với sông } \\
\text { Sài Gòn }\end{array}$ \\
\hline \multicolumn{7}{|c|}{ Sông Đồng Nai } \\
\hline 14 & $\begin{array}{l}\text { Hiếu Liêm- } \\
\text { Thủy điện } \\
\text { Trị An }\end{array}$ & DNL1 & 738880 & 1239992 & $\begin{array}{l}\text { Cửa ra Hồ Trị An vào } \\
\text { sông Đồng Nai }\end{array}$ & $\begin{array}{l}\text { Hồ Trị A trước khi chảy } \\
\text { vào sông Đồng Nai }\end{array}$ \\
\hline 15 & $\begin{array}{l}\text { Ngã ba sông } \\
\text { Bé-sông } \\
\text { Đồng Nai }\end{array}$ & DNL2 & 714121 & 1228955 & Bến phà Hiếu Liêm & $\begin{array}{l}\text { Hợp lưu sông Bé và sông } \\
\text { Đồng Nai }\end{array}$ \\
\hline 16 & Cầu An Hảo & DNL5 & 702017 & 1203356 & Cầu An Hảo & $\begin{array}{l}\text { Ngã } 3 \text { hợp lưu sông } \\
\text { Đồng Nai đi vào TP. } \\
\text { Biên Hòa (Hóa chất Biên } \\
\text { Hòa, Nhựa Đồng Nai, }\end{array}$ \\
\hline
\end{tabular}




\begin{tabular}{|c|c|c|c|c|c|c|}
\hline No. & Vị trí & Ký hiệu & $\mathbf{X}(\mathbf{m})$ & $\mathbf{Y}(\mathbf{m})$ & Mô tả & $\begin{array}{c}\text { Lý do lựa chọn } \\
\text { vị trí lấy mẫu }\end{array}$ \\
\hline & & & & & & Cty Proconco, ) \\
\hline 17 & $\begin{array}{l}\text { Cửa Rạch } \\
\text { Đồng Tròn }\end{array}$ & DNL6 & 702810 & 1199387 & $\begin{array}{l}\text { Vị trí cửa ra Rạch Đồng } \\
\text { Tròn-sông Đồng Nai }\end{array}$ & $\begin{array}{l}\text { Từ Rạch Đồng Tròn hợp } \\
\text { lưu với sông Đồng Nai }\end{array}$ \\
\hline 18 & $\begin{array}{l}\text { Ngã ba sông } \\
\text { Tắc-sông } \\
\text { Soài Rạp }\end{array}$ & DNL8 & 701024 & 1192244 & $\begin{array}{l}\text { Ngay vị trí cửa ra của } \\
\text { sông Tắc vào sông Soài } \\
\text { Rạp-sông Đồng Nai }\end{array}$ & $\begin{array}{l}\text { Cửa ra sông Tắc vào } \\
\text { sông Soài Rạp-sông } \\
\text { Đồng Nai }\end{array}$ \\
\hline
\end{tabular}

\subsection{Dưng cu lấy mẫu nuớc và trầm tích}

Chọn vị trí lấy mẫu nước mặt này là những vị trí dòng chảy có thể mang một lượng lớn rác thải nhựa từ thượng nguồn sông Sài Gòn chảy qua các khu dân cư đông đúc và khu công nghiệp của $\mathrm{Tp}$. HCM và tỉnh Bình dương. Các mẫu nước mặt được thu thập từ năm 2020-2021 bằng cách sử dụng lưới Newston có kích thước $1 \times 1 \mathrm{~m}^{2}$ mắt lưới $500 \mu \mathrm{m}$ được ghép nối với nhau dài 3 mét. Các lưới được đặt cạnh nhau kết nối bằng các thanh nhôm ở phía trên và phía dưới. Các lưới kết nối với chiếc thuyền bằng dây thép và một cái móc lớn. (Hình $2 \mathrm{~b}$ ). Có gắn thiết bị đo lưu tốc dòng cũng được sử dụng để đo vận tốc dòng nước tại thời điểm lấy mẫu. Mẫu sẽ được lấy tại 02 vị trí giữa dòng và hai bên bờ, thời gian lấy mẫu khoảng 30 phút/vị trí vào lúc triều xuống.

(a)

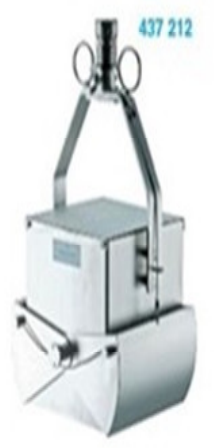

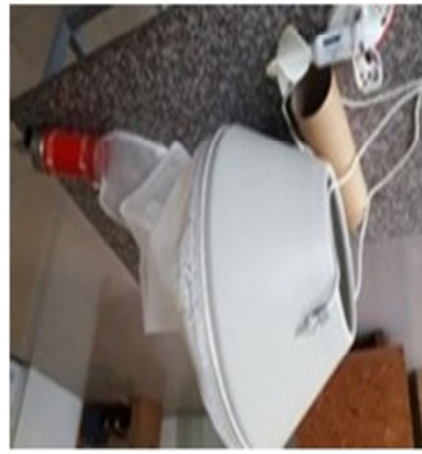

(b)

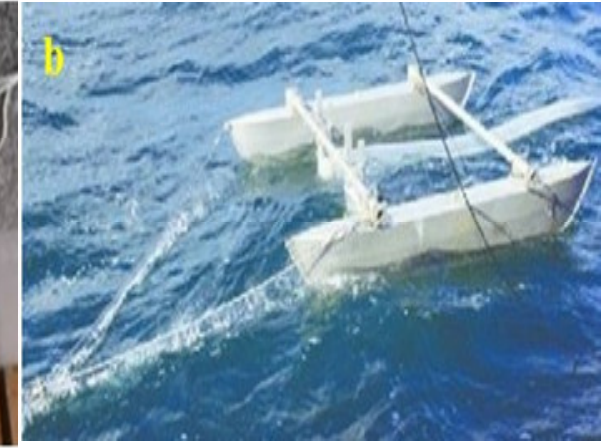

Hình 2. Dụng cụ lấy mẫu vi nhựa trong trầm tích và nước mặt: (a) Gầu lấy mẫu vi nhựa trong trầm tích; (b) bộ thu mẫu Neuton với lưới $500 \mu \mathrm{m}$.

Các mẫu nước để phát hiện mật độ nhựa sử dụng lưới kéo từ các vị trí (1-18) bảng 1; chiều dài kéo lấy mẫu là $300 \mathrm{~m}$, lưới ngập sâu $2-4 \mathrm{~m}$. Thu mẫu vi nhựa trong trầm tích: Mẫu vi nhựa lẫn trong trầm tích ở lớp 2-10 cm sẽ được lấy bằng gàu thu mẫu chuẩn Ekman-Birge kích thước $20 \times 20 \times 35 \mathrm{~cm}$ (Hình 2a). Mẫu sẽ được lấy tại 02 vị trí cách nhau $20 \mathrm{~m}$ (giữa dòng và hai bên bờ).

\subsection{Phuơng pháp phân tích thành phần vi nhựa trong nước mặt và trầm tích}

Nghiên cứu mẫu trầm tích, vị trí lấy mẫu trầm tích cùng với vị trí lấy mẫu nước, phương pháp xác định FTIR SEM/EDS, trầm tích được lấy bằng gầu lấy mẫu, diện tích lấy mẫu là $500 \mathrm{~cm}^{2}$, độ sâu $2-10 \mathrm{~cm}$, khối lượng mẫu là $0,5 \mathrm{~kg} / \mathrm{mẫu}$. Sơ đồ các bước thực hiện phân tích vi nhựa được thể hiện trong hình 3. 


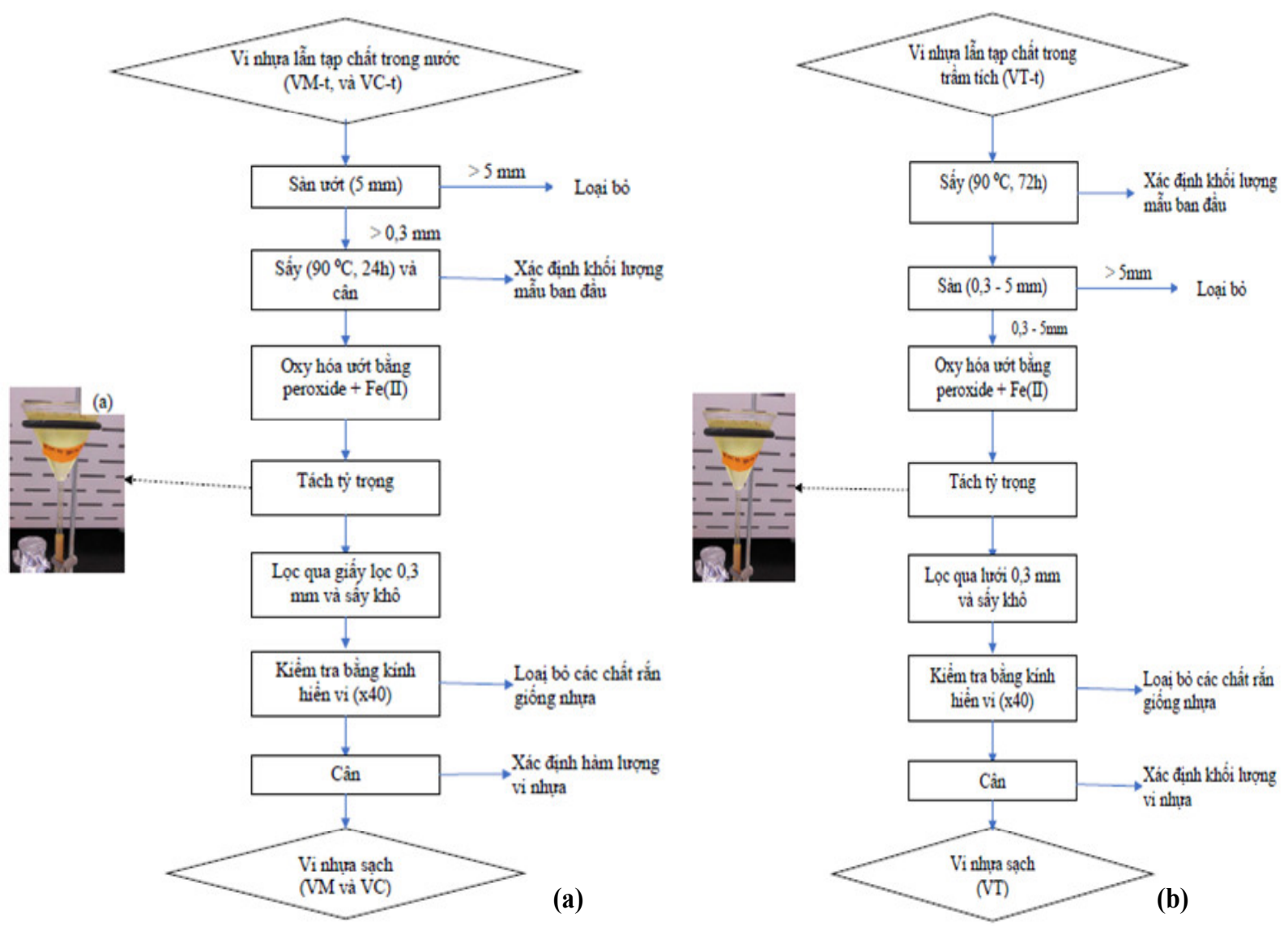

Hình 3. Sơ đồ thực hiện phân tích vi nhựa: (a) Vi nhựa trong nước; (b) Vi nhựa trong trầm tích.

\subsection{Phưong pháp kính hiển vi điện tư quét (SEM - Scanning Electron Microscope)}

Kính hiển vi điện tử tạo ra ảnh với độ phân giải cao của bề mặt mẫu vật bằng cách sử dụng một chùm điện tử quét trên bề mặt mẫu. Việc tạo ảnh của mẫu vật được thực hiện thông qua việc ghi nhận và phân tích các bức xạ phát ra từ tương tác của chùm điện tử với bề mặt mẫu vật, xác định kích thước hạt vi nhựa. Sau quá trình xử lý, mẫu được đặt dưới kính hiển vi điện tử quét Jeol $5410 \mathrm{LV}$, độ phóng đại $40 \mathrm{X}$ và tất cả các hạt vi nhựa có mặt được đếm và xác định là mảnh, viên, đường/sợi, màng hoặc bọt. Thông tin này cho tất cả các loại kích thước ghi lại trên một bảng dữ liệu cho mỗi mẫu. Các hạt vi nhựa được xác định, sau đó đặt vào lọ thủy tinh có nắp $4 \mathrm{~mL}$ và dán nhãn niêm phong và cất giữ, bảo quản.

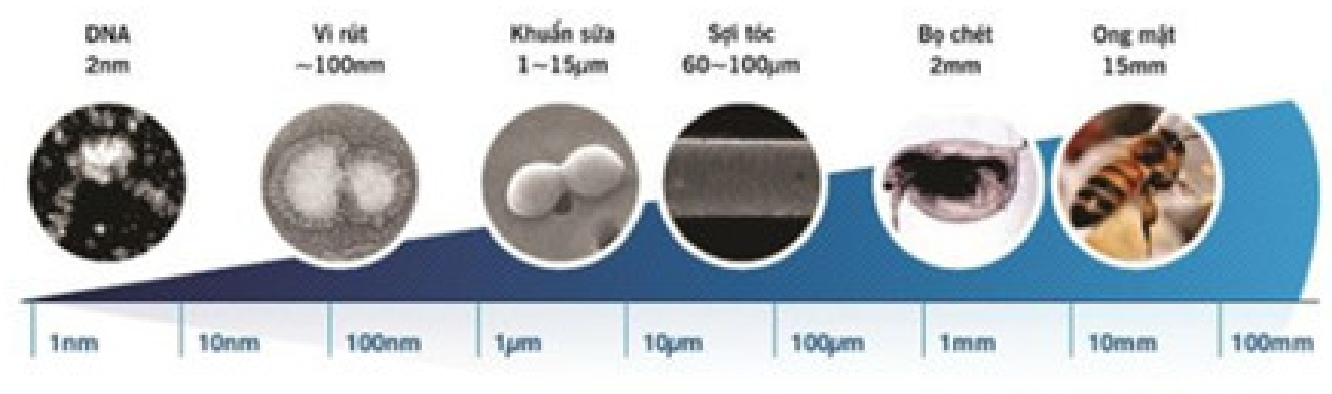

Quan sit đugse bing mbt thatne

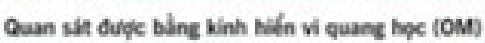

Quan sit dưke bing kinh híh vi oifn tù (SEM)

Hình 4. Ngưỡng quan sát được của SEM. 


\subsection{Quang phổ hấp phu FTIR (Fourrier Transformation InfraRed)}

Phương pháp FTIR (Fourrier Transformation InfraRed) hoạt động dựa trên sự hấp thụ bức xạ hồng ngoại của vật chất cần nghiên cứu. Phương pháp này ghi nhận các dao động đặc trưng của các liên kết hóa học giữa các nguyên tử. Phương pháp này cho phép phân tích với hàm lượng chất mẫu rất thấp và có thể phân tích cấu trúc, định tính và định lượng. Có thể đạt dộ nhạy rất cao ngay cả khi mẫu chỉ có bề dày cỡ $50 \mathrm{~nm}$... Việc xác định các hạt vi nhựa được hỗ trợ bằng cách sử dụng máy quét quang phổ hồng ngoại biến đổi Fourier (FTIR). Để phân tích FTIR, các lọ mẫu đã được rửa sạch và đổ vào đĩa petri khô, sạch, có dán nhãn (được phân cách theo phần kích thước) và đặt trong lò sấy ở nhiệt độ $50^{\circ} \mathrm{C}$ cho đến khi đĩa petri và các chất bên trong khô. Các hạt riêng lẻ sau đó được di chuyền khỏi đĩa petri bằng kính hiển vi (Leica EZ4HD, zoom 8-40x, camera 3Mpixel tích hợp) và được đặt trên FTIR (PerkinElmer Spectrum Two ATR; 450/cm đến 4000/cm, 64 lần quét, độ phần giải $4 / \mathrm{cm}$ ). Các phổ thu được được so sánh với các thư viện quang phổ để tìm ra sự trùng khớp gần nhất và xác định thành phần hóa học. Độ trùng khớp từ $70 \%$ trở lên được coi là đủ để xác nhận.

\subsection{Xủ lý số liệu}

Kết quả phân tích thành phần số lượng và khối lượng hạt vi nhựa được tính toán giá trị trung bình bằng Microsoft Excel, và phần mềm Sigmaplot 12.0. Kích thước của các hạt vi nhựa dưới kính hiển vi được xác định bằng phần mềm Image Focus v3.0.

\section{Kết quả và thảo luận}

\subsection{Mức độ tập trung của vi nhựa trong môi trương nước mặt}

Kết quả ban đầu phân tích nước mặt có hàm lượng vi nhựa lớn, có từ 228.120 sợi vi nhựa/ $\mathrm{m}^{3}$ nước, nhiều nhất 715.124 sợi vi nhựa $/ \mathrm{m}^{3}$ nước (mẫu nước lấy ven bờ sông $3-5 \mathrm{~m}$ ), 23-300 mảnh và màng vi nhựa/ $\mathrm{m}^{3}$ nước có kích thước nhỏ hơn $<5 \mathrm{~mm}$ (mẫu lấy giữa sông ở độ sâu 2-4 m).

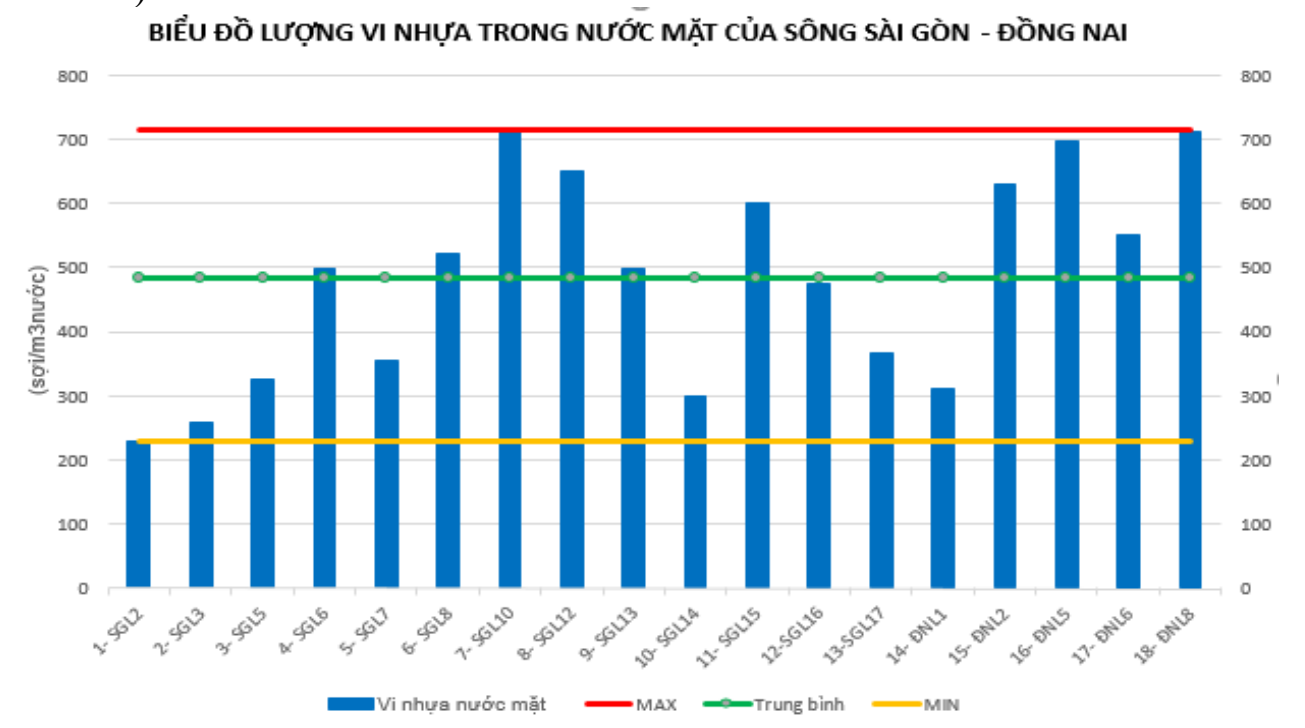

Hình 5. Vi nhựa dạng sợi tại các điểm thu mẫu.

\subsection{Mức độ tập trung của vi nhựa trong môi truờng trầm tích}

Mẫu được phân tích có khoảng 38-498 mảnh/kg trầm tích khô, mảnh nhựa có kích thước từ $0,1 \mathrm{~mm}$ và $0,1-0,5 \mathrm{~mm}$ là chủ yếu, trong đó nhựa kết quả thu được nhựa PE chiếm $51,2 \%$, PP chiếm $27,1 \%$, PVC chiếm $13,4 \%$ và $8,3 \%$ là các loại nhựa khác. 
Kết quả nghiên cứu cho thấy khối lượng hạt vi nhựa trong trầm tích tại các điểm lấy mẫu (1-SGSL2, 3-SGSL3, 5-SGSL5, 7-SGSL6, 9-SGSL13) dao động từ 6,47 $\pm 1,45$ đến $52,32 \pm 4,92 \mathrm{mg} / \mathrm{kg}$ với giá trị trung bình $21,77 \pm 6,9 \mathrm{mg} / \mathrm{kg}$. Phân bố không đồng đều về khối lượng tại các điểm lấy mẫu, (2-SGSL2, 4-SGSL6, 6-SGSL8) (Hình 5). Bước đầu cho thấy khi triều xuống có số hạt có kích thước rất khác nhau do lắng đọng tĩnh tại các vị trí ven bờ (cách bờ $5 \mathrm{~m}$ ). Tuy nhiên, để xác định được chính xác của sự khác biệt này cần tiến hành các nghiên cứu sâu trong thời gian tới để làm rõ được các yếu tố chi phối sự tích lũy, lắng đọng hạt vi nhựa trong trầm tích. Sự khác biệt về thành phần khối lượng hạt vi nhựa của các mẫu tại cùng vị trí lấy mẫu khoảng 15-20\% giá trị (Hình 6).
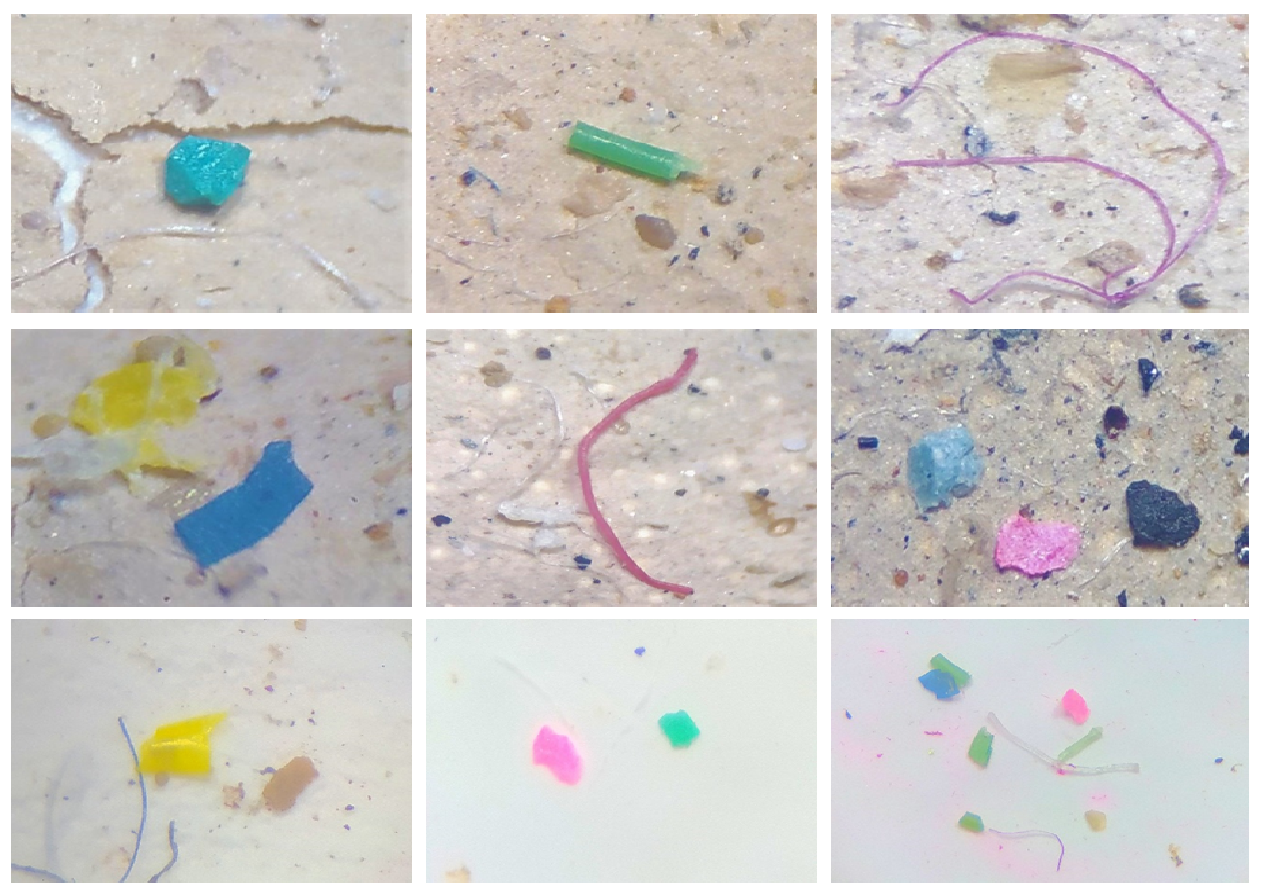

Hình 6. Kết quả xác định vi nhựa trong trầm tích dưới kính hiển vi huỳnh quang.

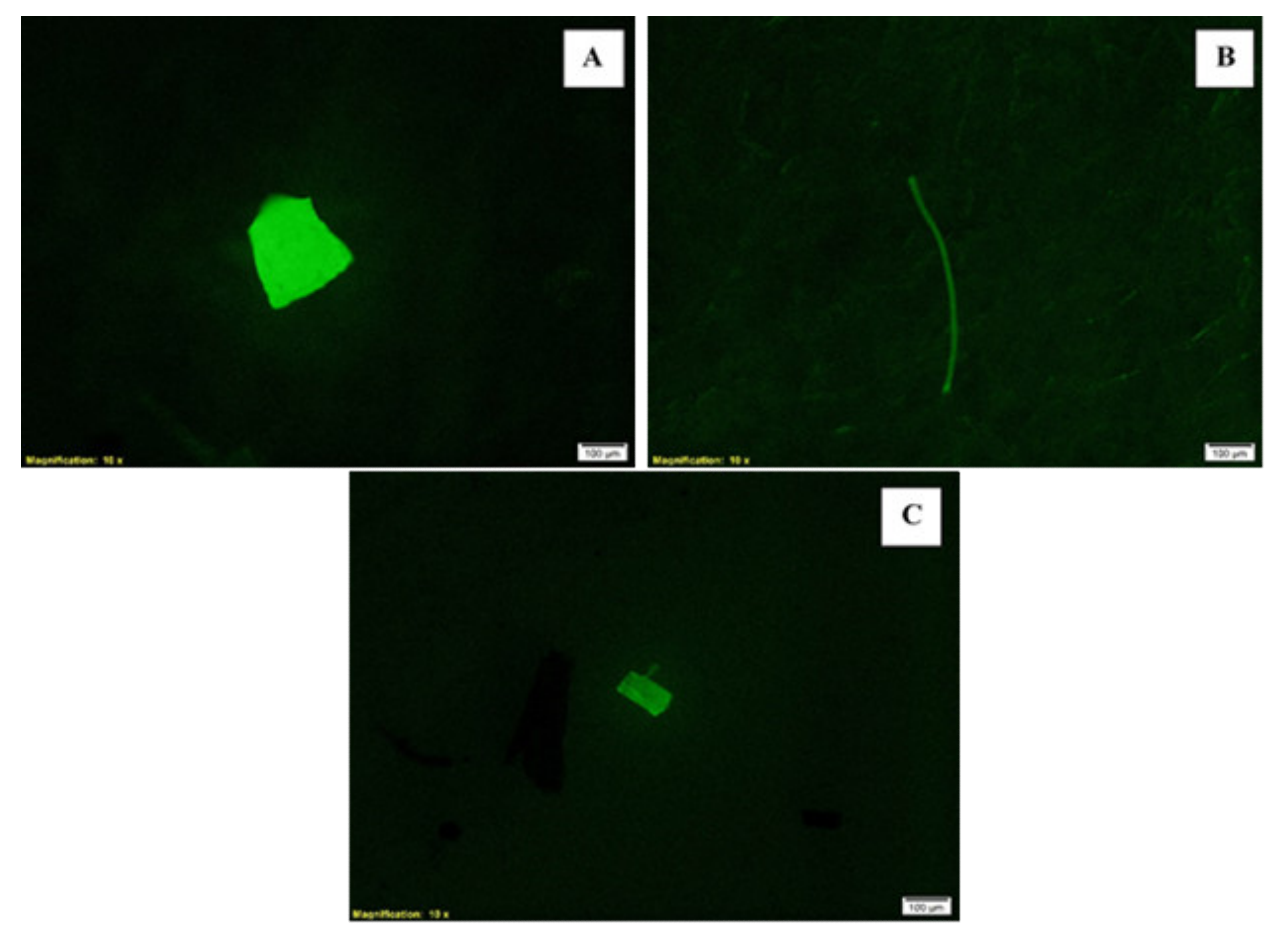

Hình 7. Với độ phóng đại 100x thể hiện vi nhựa dạng mảnh (A) có chiều dài $229,49 \mu \mathrm{m}$; dạng sợi (B) có chiều dài $524,68 \mu \mathrm{m}$ và dạng hạt $(\mathrm{C})$ có chiều dài $113,81 \mu \mathrm{m}$. 


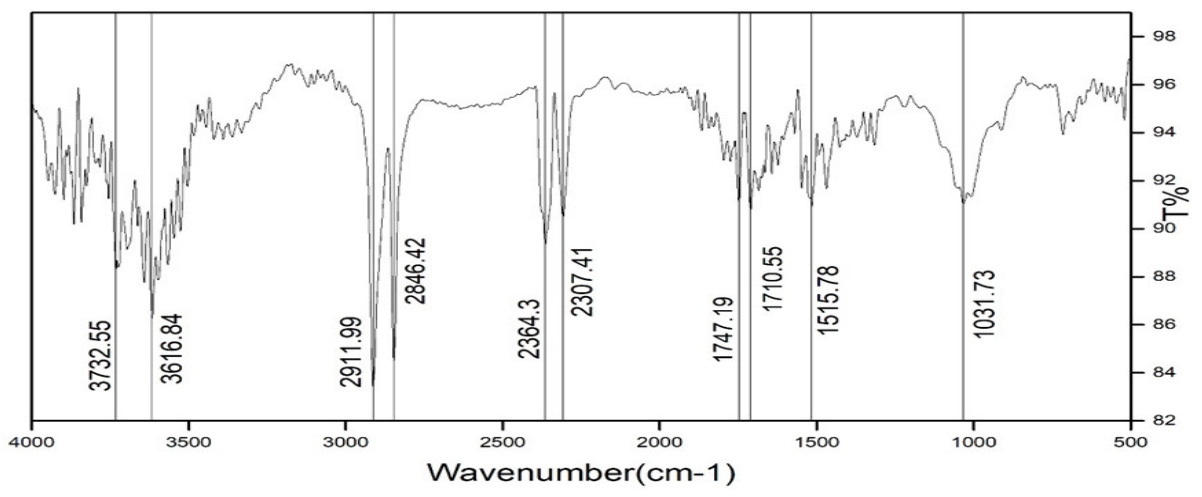

Hình 8. Kết quả định danh vi nhựa trong trầm tích bằng FTIR.

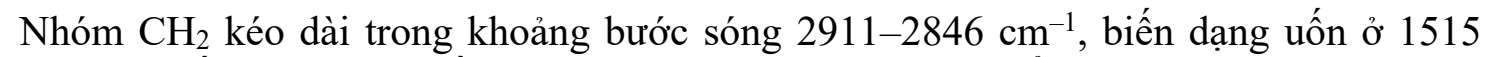
$\mathrm{cm}^{-1}$ và các biến dạng khác đều có bước sóng tương tự như phổ IR đặc trưng của HDPE. Phân tích thành phần hạt vi nhựa bằng kính hiển vi soi nổi cho thấy tổng số hạt vi nhựa dao động trong khoảng 2.873 đến 4.951 hạt vi nhựa với giá trị trung bình là 3.926 hạt vi nhựa/kg trầm tích. Tương tự như thành phần khối lượng, sự khác biệt về số lượng hạt vi nhựa trong môi trường trầm tích tại cùng một vị trí lấy mẫu là không đáng kể. So sánh với các khu vực tương tự tại Việt Nam, số lượng hạt vi nhựa trong trầm tích sông Sài GònĐồng Nai cao hơn rõ rệt.

\subsection{Thành phần số lượng hạt vi nhựa trong nước và trầm tích sông}

So sánh mức độ nhiễm bẩn vi nhựa tại sông Sài Gòn-Đồng Nai với một vài địa điểm khác tại Việt nam (Tại Cần giờ trong môi trường trầm tích là bãi cát), kích thước hạt $0,3-$ 0,5 mm, hạt vi nhựa 0-666,7 hạt vi nhựa/ $\mathrm{kg}$ [13] tại cửa Ba lạt 45-3.235 hạt vi nhựa $/ \mathrm{kg}$ [14].
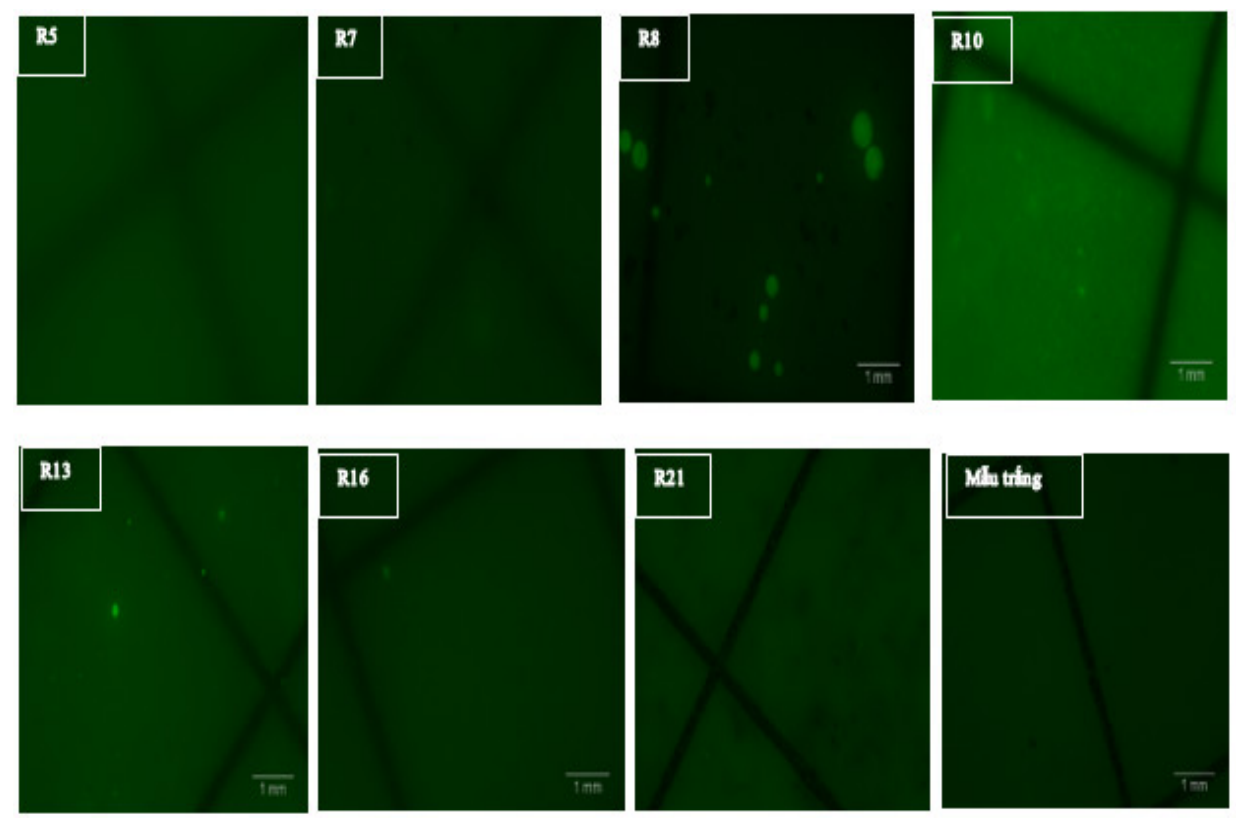

Hình 9. Mẫu vi nhựa trong nước trong trầm tích từ kính hiển vi soi nổi.

Kết quả vùng nước mặt, các vi nhựa có các màu sắc và hình dạng khác nhau, sử dụng lưới có kích thước lỗ $300 \mu \mathrm{m}$ để bắt mẫu, dùng dung dịch $\mathrm{Fe}(\mathrm{II})$ và $\mathrm{H}_{2} \mathrm{O}_{2}$ để loại bỏ chất hữu cơ dễ phân hủy, phân loại thành phần kích cỡ và hình dạng bằng kính hiển vi. Lấy mẫu bằng lưới trong 13 ngày liên tục tại cầu Thủ Thiêm, lấy mẫu từ 8:00 đến 15:00, chiều dài 
bắt mẫu là $300 \mathrm{~m}$. Ô nhiễm vi nhựa cao hơn 3-5 lần so với công bố trước đây. Khảo sát vi nhựa tại ngã ba Thanh đa, vị trí hợp lưu kênh Thanh đa và sông Sài Gòn hạ nguồn. Kết quả phân tích vi nhựa cho thấy sự tồn tại chủ yếu của sợi và mảnh vỡ nhựa với nồng độ từ $228.120 \mathrm{sợi} / \mathrm{m}^{3}$ nước đến nhiều nhất 715.124 sợi $/ \mathrm{m}^{3}$ nước và 11 đến $222 \mathrm{mảnh} / 1 \mathrm{~m}^{3}$ nước.

\section{Kết luận}

Nghiên cứu sự phát thải vi nhựa trong nước mặt và trầm tích sông Sài Gòn-Đồng Nai góp phần vào công tác bảo vệ nguồn nước. Tại những vị trí lấy mẫu nghiên cứu là những nơi đông dân cư, có lượng thải chất thải rắn lớn, ngã ba hay nơi hợp lưu của những kênh, sông nhỏ vào sông Sài Gòn-Đồng Nai, đã làm cho mục đích vấn đề nghiên cứu được sáng tỏ (vị trí lấy mẫu 2-SGL3, 3-SGL5, 6-SGL8, 9-SGL13, 10-SGL14, bảng 1). Nghiên cứu còn lấy mẫu nước mặt, mẫu trầm tích xung quanh vị trí lấy lấy nước thô của nhà máy xử lý nước sinh hoạt trên sông Sài Gòn-Đồng Nai ở độ sâu $4 \mathrm{~m}$. Các số liệu nghiên cứu cho thấy mức độ phát thải vi nhựa trên sông Sài Gòn- Đồng Nai ở dạng mảnh, hạt, dạng sợi vi nhựa cao hơn các nghiên cứu trước từ 3-5 lần. Kết quả phân tích nước mặt có hàm lượng vi nhựa lớn, có từ 228.120 sợi vi nhựa $/ \mathrm{m}^{3}$ nước, nhiều nhất 715.124 sợi vi nhựa $/ \mathrm{m}^{3}$ nước. Khối lượng hạt vi nhựa trong trầm tích tại các điểm lấy mẫu (1-SGSL2, 3-SGSL3, 5-SGSL5, 7SGSL6, 9-SGSL13) dao động từ $6,47 \pm 1,45$ đến $52,32 \pm 4,92 \mathrm{mg} / \mathrm{kg}$ với giá trị trung bình $21,77 \pm 6,9 \mathrm{mg} / \mathrm{kg}$. Phân bố không đồng đều về số lượng, khối lượng tại các điểm lấy mẫu, (2-SGSL2, 4-SGSL6, 6-SGSL8). Xác định vi nhựa trong nước, trầm tích sông Sài Gòn Đồng Nai bước đầu cho thấy tiến hành thuận lợi và có khả năng mở rộng áp dụng cho các lưu vực sông khác.

Đóng góp của tác giả: Xây dựng ý tưởng nghiên cứu: H.P., H.T.N.H., N.L.N.T., Đ.V.Đ.; Lựa chọn phương pháp nghiên cứu: H.P., H.T.N.H., N.L.N.T., Đ.V.Đ., Phân tích mẫu: H.P., H.T.N.H., N.L.N.T., T.G.H; Lấy mẫu: H.P., H.T.N.H., N.L.N.T., T.G.H; Viết bản thảo bài báo: H.P., H.T.N.H.; Chỉnh sửa bài báo: H.P., H.T.N.H., N.L.N.T., Đ.V.Đ.

Lời cảm ơn: Nghiên cứu này được thực hiện dưới sự tài trợ của đề tài nghiên cứu Vi nhựa trong nước mặt và trầm tích sông Sài Gòn - Đồng Nai, của Viện Phát triển Công nghệ Môi trường và Tài nguyên nước Phú Mỹ.

Lời cam đoan: Tập thể tác giả cam đoan bài báo này là công trình nghiên cứu của tập thể tác giả, chưa được công bố ở đâu, không được sao chép từ những nghiên cứu trước đây; không có sự tranh chấp lợi ích trong nhóm tác giả.

\section{Tài liệu tham khảo}

1. Cơ quan Khí quyển và Đại dương Quốc gia (NOAA) định nghĩa vi nhựa. Andrady, 2011.

2. Phú, H.; Hân, H.T.N. Báo cáo Hội thảo "Vi nhựa trong nước và trầm tích sông Sài Gòn - Đồng Nai và nguy cơ đến sức khỏe người dân TP HCM". Viện Khoa Học Úng Dụng Hutech; Trường Đại học Công nghệ TP Hồ Chí Minh, 2021.

3. Mạnh, Đ.V. Mối nguy hại của hạt vi nhựa và Đề xuất giải pháp quản lý ô nhiễm vi nhựa hiệu quả. Thực trạng và giải pháp xử lý rác thải nhựa tại VN. Hiệp hội Môi Trường và Khu công nghiệp Việt nam, Chuyên trang quản lý môi trường (Tạp chí Môi trường và Đô thị Việt Nam) \& Công ty Informa Markets Vietnam, 2021.

4. Dũng, N.H. Hiện trạng rác thải nhựa, công tác thu gom, xử lý rác thải nhựa tại Việt Nam - Đề xuất các giải pháp tổng quan. Thực trạng và giải pháp xử lý rác thải nhựa tại VN. Hiệp hội Môi Trường và Khu công nghiệp Việt nam, Chuyên trang quản lý môi trường (Tạp chí Môi trường và Đô thị Việt Nam) \& Công ty Informa Markets Vietnam, 2021. 
5. Hernandez, E.; Nowack, B.; Mitrano, D.M. Polyester textiles as a source of microplastics from households: a mechanistic study to understand microfiber release during washing. Environ. Sci. Technol. 2017, 51(12), 7036-7046.

6. Dũng, L.V.; Dực, T.H.; Hà, N.T.H.; Tùng, N.D.; Tuệ, N.T.; Hiếu, P.V.; Định, N.Q.; Nhuận, M.T. Nghiên cứu phương pháp xác định hạt vi nhựa trong môi trường trầm tích bãi triều ven biển, áp dụng thử nghiệm tại xã Đa Lộc, huyện Hậu Lộc, tỉnh Thanh Hóa. Tạp chi Khi tuợng Thủy văn 2020, 715, 1-12.

7. Bakir, A.; Rowland, S.J.; hompson, R.C. Transport of persistent organic pollutants by microplastics in estuarine conditions. Estuarine Coastal Shelf Sci. 2014, 140, $14-21$.

8. Eriksen, M.; Mason, S.; Wilson, S.; Box, C.; Zellers, A.; Edwards, W.; Farley, H.; Amato, S. Microplastic pollution in the surface waters of the Laurentian Great Lakes. Mar. Pollut. Bull. 2013, 77, 177-182.

9. Faure, F.; Corbaz, M.; Baecher, H.; de Alencastro, L. Pollution due to plastics and microplastics in Lake Geneva and in the Mediterranean Sea. Archival Sci. 2012, 65, $157-164$.

10. Dekiff, J.H.; Remy, D.; Klasmeier, J.; Fries, E. Occurrence and spatial distribution of microplastics in sediments from Norderney. Environ. Pollut. 2014, 186, 248 256.

11. Jahan, S.; Strezov, V.; Weldekidan, H.; Kumar, R.; Kan, T.; Sarkodie, S.A. Interrelationship of microplastic pollution in sediments and oysters in a seaport environment of the eastern coast of Australia. Sci. Total Environ. 2019, 695, 133924.

12. Peng, G.; Xu, P.; Zhu, B.; Bai, M.; Li, D. Microplastics in freshwater river sediments in Shanghai, China: A case study of risk assessment in mega-cities. Environ. Pollut. 2018, 234, 448-456.

13. Peng, G.; Zhu, B.; Yang, D.; Su, L.; Shi, H.; Li, D. Microplastics in sediments of the Changjiang Estuary, China. Environ. Pollut. 2017, 225, 283-290.

14. Su, L.; Cai, H.; Kolandhasamy, P.; Wu, C.; Rochman, C. M.; Shi, H. Using the Asian clam as an indicator of microplastic pollution in freshwater ecosystems. Environ. Pollut. 2018, 234, 347-355.

15. Su, L.; Xue, Y.; Li, L.; Yang, D.; Kolandhasamy, P.; Li, D.; Shi, H. Microplastics in Taihu Lake, China. Environ. Pollut. 2016, 216, 711-719.

16. Vaughan, R.; Turner, S.D.; Rose, N. L. Microplastics in the sediments of a UK urban lake. Environ. Pollut. 2017, 229, 10-18.

17. Wang, W.; Ndungu, A.W.; Li, Z.; Wang, J. Microplastics pollution in inland freshwaters of China: A case study in urban surface waters of Wuhan, China. Sci. Total Environ. 2017b, 575, 1369-1374.

18. Zhang, K.; Su, J.; Xiong, X.; Wu, X.; Wu, C.; Liu, J. Microplastic pollution of lakeshore sediments from remote lakes in Tibet plateau, China. Environ. Pollut. 2016, 219, 450-455.

19. Barnes, D.K.A.; Galgani, F.; Thompson, R.C.; Barlaz, M. Accumulation and fragmentation of plastic debris in global environments. Philos. Trans. R. Soc. London, Ser. B 2009, 364, 1985-1998.

20. Zhao, S.; Zhu, L.; Wang, T.; Li, D. Suspended microplastics in the surface water of the Yangtze Estuary System, China: First observations on occurrence, distribution. Mar. Pollut. Bull. 2014, 86, 562-568.

21. Free, C.M.; Jensen, O.P.; Mason, S.; Eriksen, M.; Williamson, N.J.; Boldgiv, B. High-levels of microplastic pollution in a large, remote, mountain lake. Mar. Pollut. Bull. 2014, 85, 156-163. 
22. Mani, T.; Hauk, A.; Walter, U.; Burkhardt-Holm, P. Microplastics profile along the Rhine River. Sci. Rep. 2015, 5, 17988.

23. Wang, W.; Ndungu, A.W.; Li, Z.; Wang, J. Microplastics pollution in inland freshwaters of China: A case study in urban surface waters of Wuhan, China. Sci. Total Environ. 2016, 575, 1369-1374.

24. Nhơn, N.T.T.; Vy, Đ.T.Y.; Nguyên, N.T.; Hiền, T.T. Vi nhựa trong cát biển Cần Giờ, Thành phố Hồ Chí Minh. Kỷ yếu hội thảo Ô nhiễm rác thải nhựa trên biển Việt Nam: Thực trạng và giải pháp 2019, 139-148.

25. Nguyên, N.T.; Ngân, N.T.K.; Như, H.; Đông, H.K.; Nhơn, N.T.T. Đặc trưng ô nhiễm vi nhựa tại 3 vùng biển Cần Thơ, Tiền Giang và Bà Rịa Vũng Tàu. Hội thảo rác thải nhựa, Viện Tài nguyên môi trường, ĐHQG Hà Nội, 2019.

26. Hien, H.T.; Lan, H.T.; Trang, T.D.M.; Cuc, N.T.T.; Sen, T.M.; Long, N.T. Initial results of microplastics on the sediment surface in the Balat river mouth, Northern Vietnam. Kỷ yếu hội thảo Ô nhiễm rác thải nhựa trên biển Việt Nam: Thực trạng và giải pháp, 2019, 130-138.

\title{
Study on the dispersion of microplastic pollution in water and sediments of Sai Gon-Dong Nai River
}

\section{Phu Huynh ${ }^{1^{*}}$, Ngoc Han Huynh Thi $^{2}$, Ngoc Thao Nguyen Ly ${ }^{1}$, Dong Van Dang ${ }^{3}$, Han Trinh Gia ${ }^{4}$}

${ }^{1}$ Hochiminh City University of Technology (HUTECH); h.phu@hutech.edu.vn, nln.thao@hutech.edu.vn

${ }^{2}$ Hochiminh City University of Natural Resources and Environment; htnhan_ctn@hcmunre.edu.vn

${ }^{3}$ DongVinh Co., Ltd; Sales@dovitech.com.vn

${ }^{4}$ Graduate student: giahann1296@gmail.com

\begin{abstract}
The Sai Gon-Dong Nai River, which provides up to $94 \%$ of raw water to produce drinking and domestic water for the people of Ho Chi Minh City. This paper presents a method of sampling at 18 locations (13 locations on the Sai Gon River and 5 locations on the Dong Nai River), analyzing microplastics in surface water and sediments. Water sources are not only polluted by organic matter and physicochemical parameters but also by microplastic emissions. The results showed the appearance of microplastics in the form of thin, fibrous and microplastic particles from $0.1-5 \mathrm{~mm}$ in size. There were 228,120 fibers $/ \mathrm{m}^{3}$ of water to a maximum of 715,124 fibers $/ \mathrm{m}^{3}$ of water and 11 to 222 pieces $/ \mathrm{m}^{3}$ of water, in the sediment $6.47 \pm 1.45$ to $52.32 \pm 4.92 \mathrm{mg} / \mathrm{kg}$, an average of 21.77 $\pm 6.9 \mathrm{mg} / \mathrm{kg}$. Of which PE 51.2\%, PP 27.1\%, PVC $13.4 \%$ and $8.3 \%$ are other plastics.
\end{abstract}

Keywords: Surface water; Sai Gon-Dong Nai River; Sediment; Microplastics. 